\title{
金属錯体による実験糖尿病の治療
}

\author{
桜井弘
}

\section{Treatment of Diabetes in Experimental Animals by Metallocomplexes}

\author{
Hiromu SAKURAI \\ Institute for Oriental Medicine, Suzuka University of Medical Science, \\ 1001-1 Kishioka-cho, Suzuka City 510-0293, Japan
}

(Received October 15, 2007)

\begin{abstract}
The number of patients suffered from diabetes mellitus has increased over the decades probably because of both lifestyle- and diet-changes. There are two types of diabetes mellitus. Type 1 diabetes mellitus is due to the autoimmunemediated destruction of pancreatic B cells, which results in absolute insulin deficiency, thus the patients require insulin injections. Type 2 diabetes mellitus is due to the insulin resistance and abnormal insulin secretion, thus the patients require exercise, diet control and/or oral hypoglycemic medicines. Each treatment, however, has some problems involving physical and mental burden, and formation of self-antibodies for insulin injections, and the severe side effects and discontinuation of insulin synthesis in the pancreas for hypoglycemic medicines. To overcome these important problems and find the replacements for the insulin injections and synthetic medicines, we attempted to develop new antidiabetic metallocomplexes with novel structures and mechanisms. In 1990, we first presented orally active vanadyl ( +4 oxidation state of oxo-vanadium) complexes including vanadyl-cysteine methyl ester complex, which normalized hyperglycemia in the streptozocin (STZ)-induced type 1 diabetic rats. Based on these findings, we have developed a wide variety of vanadyl complexes with different coordination environments around vanadyl ion. Following the study, we also challenged to develop orally active zinc complexes since 2002. This review focuses on our recent development of vanadyl and zinc complexes for anti-diabetic and anti-metabolic syndromes, together with the propose for the possible action mechanism of these complexes in adipocytes.
\end{abstract}

Key words__ diabetes; metal complex; vanadium; zinc; glucose transporter (GLUT4); metabolic syndrome

\section{1.はじめに}

わが国で 3 年毎に報告される厚生労働省の患者調 査の概況によると，2005 年の総患者数（継続して 医療を受けている患者数の推計值）と前回（2003 年）の調査結果との増減（カッコ内で示す）は，以 下の通りである.1)

$\begin{array}{lll}\text { 高血圧性疾患 } & 780 \text { 万 } 9000 \text { 人 } & (11.7 \% \text { の増加 }) \\ \text { 歯支持組織疾患 } & 566 \text { 万 } 4000 \text { 人 } & (16.3 \% \text { の増加 }) \\ \text { 糖尿病 } & 246 \text { 万 } 9000 \text { 人 } & (8.0 \% \text { の増加 }) \\ \text { 悪性新生物 } & 142 \text { 万 } 5000 \text { 人 } & (11.1 \% \text { の増加 }) \\ \text { 脳血管疾患 } & 136 \text { 万 } 5000 \text { 人 } & (0.6 \% \text { の減少 }) \\ \text { 白内障 } & 128 \text { 万 } 8000 \text { 人 } & (0.3 \% \text { の減少 })\end{array}$

鈴鹿医療科学大学 東洋医学研究所（５ 510-0293 鈴鹿 市岸岡町 1001-1)

e-mail: sakuraih@suzuka-u.ac.jp

本総説は, 日本薬学会第 127 年会シンポジウム S29 で 発表したものを中心に記述したものである.
喘息 109 万 2000 人 $(2.1 \%$ の増加 $)$

糖尿病の患者数は第 3 位であり，その内訳は，男 性 132 万 3000 人，女性 114 万 6000 人である. ここ で糖尿病と認定された患者とは，血液中の糖化へモ グロビン $\left(\mathrm{HbA}_{1 \mathrm{C}}\right)$ 濃度が $6.1 \%$ 以上を示したもの である。 $\mathrm{HbA}_{1 \mathrm{C}}$ 濃度が 5.6-6.1\%である糖尿病の可 能性を否定できない人をも含めると，総患者数は 500 万人を超えると考えられている.

WHO によると，糖尿病は大きく 2 タイプに分類 される. ${ }^{2)}$

1 型糖尿病は, 膵臓ランゲルハンス氏島の $\mathrm{B}$ 細胞 の破壊によるインスリンの絶対的な不足によるもの である，原因には，ウイルス感染などが引き金とな る自己免疫によるものと，特発性によるものが知ら れている。1 型糖尿病は, どの年齢においても発症 の可能性はあるが, 大部分は 15 歳未満の小児にみ られる。 
2 型糖尿病には，インスリン分泌の低下を主体と するものとインスリン抵抗性が主体で，インスリン 作用の相対的不足を伴うものが知られている．2 型 糖尿病の発症原因としては，遺伝的異常に過食，偏 食，運動不足やストレスなどの生活習慣が加わるも のと考えられており，大部分は中高年に発症する. わが国での糖尿病の大部分は，この 2 型糖尿病であ る.

1 型糖尿病の治療には，インスリン注射が必須で あり,これには作用の時間差を持たせたいくつかの 種類の製剤が開発されている。しかし，インスリン 注射は小児にとっては肉体的・精神的な負担が大き く，インスリン注射に替わり得る経口剂の開発が望 まれている，一方，2 型糖尿病の治療は，食事・運 動療法が第一選択であるが，これらにより改善がみ られない場合には，合成血糖降下剂が与えられる。

スルホニル尿素剤，グリニド系薬剤，ビグアニド系 薬剤, グリタゾン系薬剤や $\alpha$-グルコシダーゼ阻害 剂などが，単独か若しくは複合して与えられてい る。これらの血糖降下剤には副作用発現の問題があ る上，これらを長期に渡って服用すると，膵臓 B 細胞においてインスリン合成能が低下して，ついに はインスリン注射に頼らざるを得なくなる場合も知 られている，最近，糖尿病発症のメカニズムが少し ずつ明らかにされつつある状況を反映して，それら のメカニズムを利用した薬剤の開発も試みられてい る.

こうした負担の大きいインスリン注射や副作用の 多い合成血糖降下剂に替わり得る新しいタイプの薬 剂の開発が，世界的に望まれている。このような状 況下で，われわれの研究グループでは，新しい概念 を持った糖尿病治療薬として金属錯体の有用性を提 案してきた. ${ }^{3-9)}$

1990 年に，われわれは，1 型実験糖尿病ラットを 用いてインスリン注射に替わり得る，1日 1 回の経 口投与で有効な血糖降下作用を示す第 1 世代の 4 価 バナジウム [オキソバナジウム $(\mathrm{IV}), \mathrm{VO}^{2+}$ ，すな わち，一般的にバナジルと呼ばれる］錯体を初めて 提案した (Fig. 1).10)すなわち，バナジルーシステ インメチル $\left[\mathrm{VO}(\mathrm{cysm})_{2}\right](1) ，-$ シュウ酸 $\left[\mathrm{VO}(\mathrm{ox})_{2}\right](8),-$ サルチルアルデヒド $\left[\mathrm{VO}(\mathrm{sa})_{2}\right]$, 一マロン酸 $\left[\mathrm{VO}(\mathrm{ma})_{2}\right](9)$ 錯体及び複核錯体のバナ ジル-酒石酸 (12) 錯体である。バナジウム錯体に続
いて，ジンク（亜鉛： $\mathrm{Zn}^{2+}$ ) 錯体（Fig. 2) にも注 目し，2002 年に初めて 1 日 1 回の経口投与で血糖 降下作用を示すジンクーピコリン酸 $\left[\mathrm{Zn}(\mathrm{pc})_{2}\right](1)$ やーマルトール $\left[\mathrm{Zn}(\mathrm{mal})_{2}\right]$ (12) 錯体を見い出し た. ${ }^{11)}$ 本稿では，これまでに提案してきたバナジル 及びジンク錯体を中心として，抗糖尿病作用を持つ 金属錯体の開発研究の重要性を紹介することとする.

\section{2. 血糖降下作用を示すバナジル錯体}

1 日 1 回の経口投与で有効に血糖降下作用を示す バナジルーシステインメチル $\left[\mathrm{VO}(\mathrm{cysm})_{2}\right]$ などの 発見10)に続いて，1992 年にはカナダのグループか らバナジルーマルトール錯体 $\left[\mathrm{VO}(\mathrm{mal})_{2}\right] \quad[$ Fig. 1, (10) ] 12) が発表された. Figure 1 は，バナジルイオ ンの周囲に様々な配位子を組み合わせた錯体の構造 を示したものである。一方われわれは，1995 年に はバナジルーピコリン酸 $\left[\mathrm{VO}(\mathrm{pa})_{2}\right](4),{ }^{13)} 1994$ 年 にはーピロリジンジチオカルバメート $\left[\mathrm{VO}(\mathrm{pdc})_{2}\right]$ (2) , ${ }^{14)}$ そして 2004 年にはーポルフィリン (15) 錯体 が有望であることを見出した. ${ }^{15,16)}$

このような基礎的な研究をべースにして次世代の 新錯体を開発するため，いくつかのリード化合物を 設定した。

例えば，VO $\mathrm{pa})_{2}$ 錯体やバナジル -3-ヒドロキシ ピロン $\left[\mathrm{VO}(3 \mathrm{ha})_{2}\right]$ 錯体，あるいはバナジルーポル フィリン錯体をリード化合物として，新錯体の開発 を試み， $\mathrm{VO}(\mathrm{pa})_{2}$ 関連錯体では，ピコリン酸の 4 位の位置にアルキル基か若しくはハロゲン基を導入 すると，ラット脂肪細胞におけるインスリン様作用 のみならず 1 型糖尿病モデル動物の血糖值を有効に 低下させることを示した. ${ }^{17)}$ このとき，錯体の分配 係数，インビトロインスリン様作用及びインビボ血 糖降下作用の間には強い正の相関性があることも分 かった。一方， $\mathrm{VO}(3 \mathrm{ha})_{2}$ 関連錯体の構造活性相関 性に関する研究から, 乾燥ニンニク中に含まれる硫 黄を含まない成分の 1 つであるアリキシンの錯体 (11) が， 1 型及び 2 型糖尿病モデル動物に対して, 経口投与により高い血糖降下作用を示すことを見い 出した. ${ }^{18,19)}$ さらに， ポルフィリン骨格を持つバナ ジル錯体の開発も試みた。 2004 年に見い出した VO (TMpyP) 錯体 (15) は，生体内に投与すると容易に バナジルがバナデイト（+5 価バナジウム）に酸化 されるため，アスコルビン酸（ビタミンC）の併用 投与が必要であった. ${ }^{15)} し か し ， 2005$ 年に見い出し 


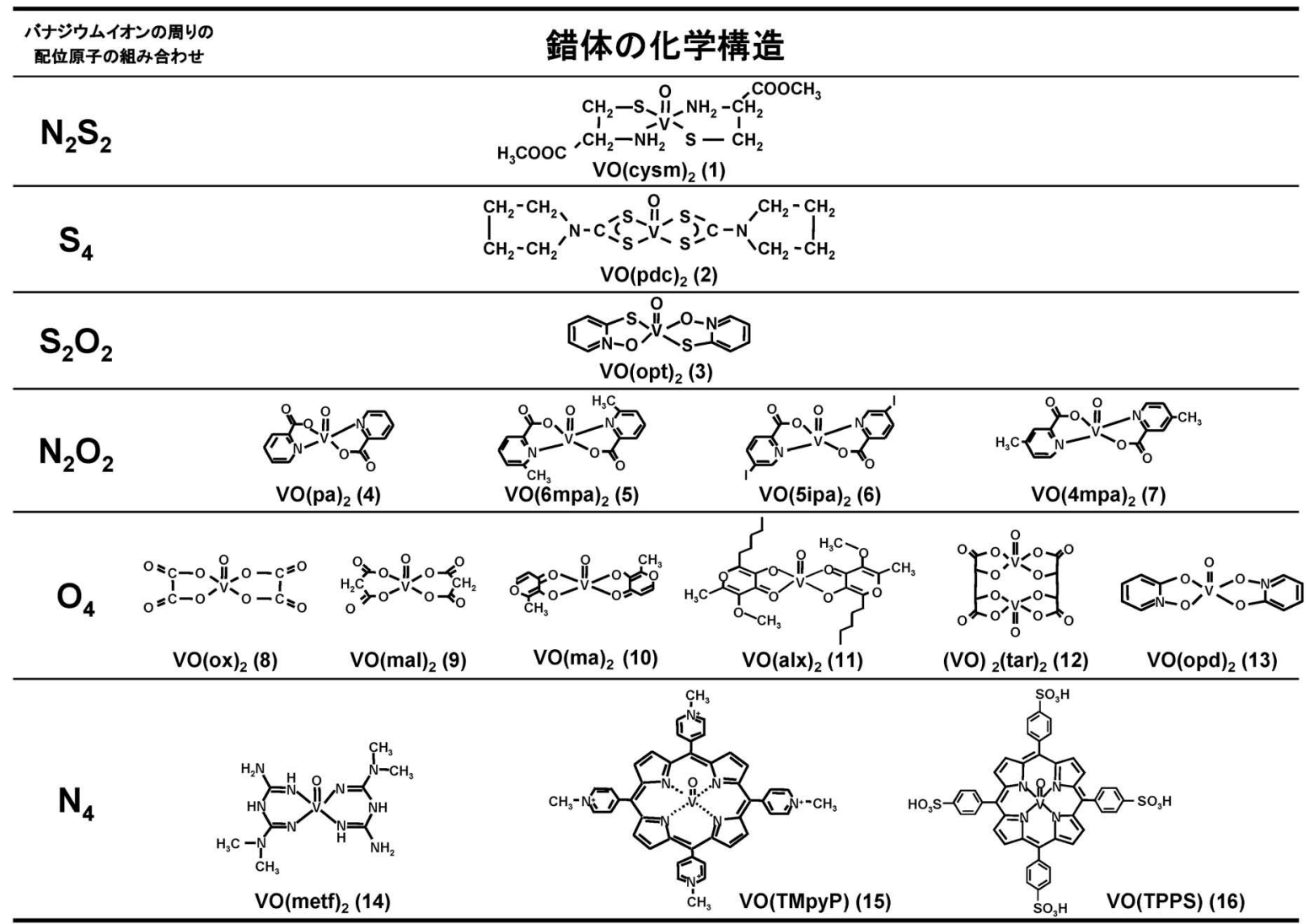

Fig. 1. Chemical Structures of Anti-diabetic Vanadyl Complexes with Different Coordination Modes

Numbers in the figure correspond to those in the text. (1), (8), (9), (12) Sakurai H. et al. (1990) J. Clin. Biochem. Nutr., 8, 193. (2) Watanabe H. et al. (1994) J. Med. Chem., 37, 876. (3) Sakurai H. et al. (1999) Chem. Lett., 913. (4) Sakurai H. et al. (1995) Biochem. Biophys. Res. Commun., 214, 1095. (5) Fujimoto S. et al. (1997) J. Clin. Biochem. Nutr., 23, 113. (6) Takino T. et al. (2001) J. Biol. Inorg. Chem., 6, 133. (7) Tayama K. et al. (2005) PACIFICHEM 2005. (10) McNeill J. H. et al. (1992) J. Med. Chem., 35, 1489. (11) Adachi Y. et al. (2006) J. Med. Chem., 49, 3251. (13) Sakurai H. et al. (2003) Coord. Chem. Rev., 245, 31. (14) Woo L. C. et al. (1999) J. Inorg. Biochem., 76, 251. (15) Sakurai H. et al. (2004) Bioorg. Med. Chem. Lett., 14, 1093. (16) Saha T. K. et al. (2005) Chem. Lett., 34, 1350.

た VO(TPPS)（16) 錯体はアスコルビン酸を併用投 与しなくても 1 日 1 回の経口投与により高い血糖降 下作用を示すことを見い出した. ${ }^{16)}$

海外では，バナジウム化合物（硫酸バナジル $\mathrm{VOSO}_{4}$ やバナジン酸ナトリウム $\mathrm{NaVO}_{3}$ ） が糖尿病 患者に実験的に経口投与され，病態の改善が報告さ

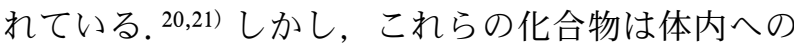
吸収率が低いため, 吸収性（bioavailability）の改 善が重大な問題である。この目的のため, 安全性の 高い高分子化合物 $\gamma$-ポリグルタミン酸と硫酸バナ ジルとを結合した錯体を合成し，それを経口投与す ると 1 型糖尿病動物の高血糖值を正常化させるこ と22) や腸溶性カプセルに硫酸バナジルやバナジル錯 体を封入するとバナジルの吸収性が増大し, ${ }^{23)}$ 血糖 降下作用が強くなることを見い出し，新しい薬物送 達システム（DDS）として，次世代錯体開発の方 向性の 1 つを示すことができた.
3. 血糖降下作用とメタボリックシンドロームを 改善するジンク錯体

ジンク（II）のインスリン様作用は，1980 年に ラットの脂肪細胞を用いた実験により証明されてい る. 致死量に近いジンク（II）化合物を腹腔内若し くは経口的に投与すると， 1 型や 2 型の実験糖尿病 の血糖值を短時間ながら低下させることも見い出さ れた (1992-2001). ${ }^{5-9)}$

そこで吸収性の低いジンクイオンの吸収性を改善 するため，錯体化を試みた。ジンク錯体は無（白） 色であり，さらにジンク（II)が反磁性であるため, 特異的な電子吸収スペクトルや電子スピン共鳴 （ESR）スペクトルを示さない。したがって，錯体 の構造は, X 線結晶構造解析法に頼らざるを得な い.また，ジンク（II）の吸収性や毒性発現の様式 はバナジル（IV) と多少異なっていることや，ジン ク錯体は 1 型糖尿病動物に対しては有効性が低いな 


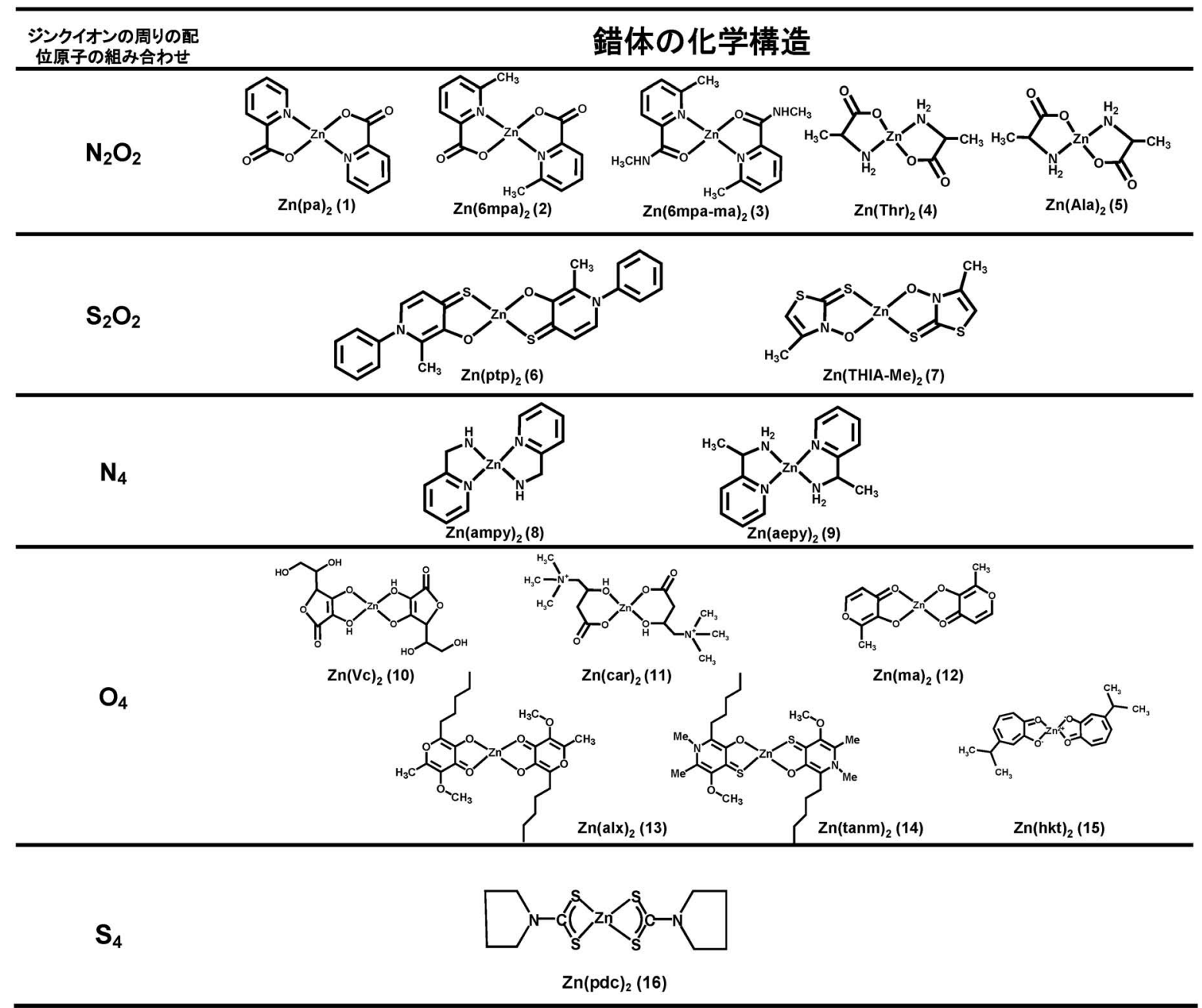

Fig. 2. Chemical Structures of Anti-diabetic Zinc Complexes with Different Coordination Modes

Numbers in the figure correspond to those in the text. (1), (2) Yoshikawa Y. et al. (2002) J. Biol. Inorg. Chem., 7, 68. (3) Yoshikawa Y. et al. (2002) Chem. Pharm. Bull., 50, 337. (4), (5) Yoshikawa Y. et al. (2001) Chem. Pharm. Bull., 49, 652. (6) Katoh A. et al. (2002) Chem. Lett., 114. (7) Japan Patent 2005182212. (8), (9) Kondo M. et al. (2001) Trace. Nutr. Res., 18, 73. (10) Kojima Y. et al. (2003) Vitamins, 77, 571-576. (11) Yoshikawa Y. et al. (2003) Chem. Pharm. Bull., 51, 230. (12) Yoshikawa Y. et al. (2001) Biochem. Biophys. Res. Commun., 281, 1190. (13) Adachi Y. et al. (2005) Chem. Lett., 34, 656. (14) Adachi Y. et al. (2006) Biochem. Biophys. Res. Commun., 351, 165. (15) Yamane M. et al. (2005) Chem. Lett., 34, 1694. (16) Yoshikawa Y. et al. (2007) Life Sci., 80, 759.

どの予備的知見が得られていた。そこで 2 型糖尿病 でかつ肥満型メタボリックシンドロームを示すモデ ル動物として考えられる KK-Ay マウスを用いて研 究することとした。

1 日 1 回ジンク（II）として $3 \mathrm{mg}(46.2 \mu \mathrm{mol}) / \mathrm{kg}$ 体重の割合で $\mathrm{Zn}(\mathrm{mal}){ }_{2}$ 錯体 [Fig. 3，（12）］を腹 腔内に投与したところ, 翌日から徐々に血糖值が低 下して， 1 週間後にはほぼ正常の血糖值となった. 錯体を 2 週間投与したのち，糖負荷試験（高濃度の グルコースを与え，経時的に血糖值を測定する）を したところ, 耐糖能も改善されていることが分かつ た．血糖值低下のみならず，糖化へモグロビン $\left(\mathrm{HbA}_{1 \mathrm{c}}\right)$ 量も低下し, 糖尿病は治癒していると判
断した. ${ }^{24)}$ さらに, $\mathrm{Zn}(\mathrm{pa})_{2}$ (1) や $\mathrm{Zn}(\mathrm{mal})_{2}$ (12) は 2 型糖尿病モデルである $\mathrm{GK}$ ラットを用いると， 経口投与により血糖降下作用を示すことが分かつ た. ${ }^{11)}$

これらの研究成果に基づいて，最近，アリキシン を配位子とした $\mathrm{Zn}(\mathrm{alx})_{2}$ 錯体（13）は 1 型糖尿病 STZ マウス ${ }^{25)}$ と 2 型糖尿病 KK-A ${ }^{\mathrm{y}}$ マウス ${ }^{26)}$ の高血 糖值をともに低下させることを明らかにした。この 研究をべースにして，さらに構造活性相関性に基づ く新錯体の合成を試みた。いくつかの錯体をテスト する中で，チオアリキシン -N- メチルを配位子とし たジンク錯体 $\left[\mathrm{Zn}(\operatorname{tanm})_{2},(14)\right]$ は 1 日 1 回の経 口投与により，KK-A ${ }^{y}$ マウスの高血糖を正常化す 


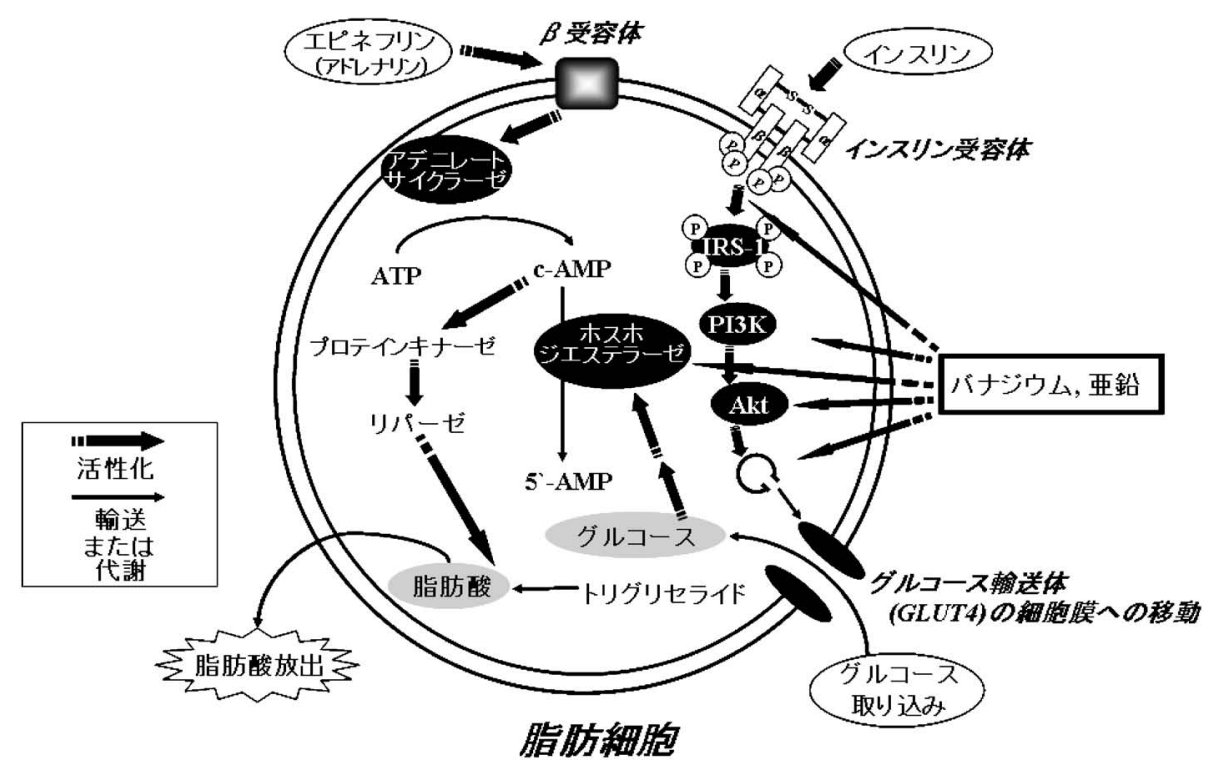

Fig. 3. A Possible Insulinomimetic Action Mechanism of Vanadium and Zinc Complexes-Ensemble Mechanism

When insulin is added to the isolated rat adipocytes, this hormone acts only on the insulin receptor, and then activates the signal transduction system, which locates in the downstream of insulin receptor. Finally, the glucose transporter (GLUT4) is translocated to the cell membrane to incorporate glucose into the cells. When vanadium or zinc compound is added to the adipocytes in place of insulin, such compound is uptaken into the cells and then acts on several action points as shown in the Figure, resulting the translocation of GLUT4 to the cell membrane and the incorporation of glucose into the cells.

るのみならずメタボリックシンドロームに関するほ ぼすべてのパラメータを改善できることが分かっ た. ${ }^{27)}$ 現在，メタボリックシンドロームのパラメー タの 1 つとしてアジポネクチンの重要性が挙げられ ているにも係わらず，これを増大させる医薬品がま だ開発されていない状況の中で，アジポネクチン濃 度を上昇させる能力を持つ $\mathrm{Zn}(\operatorname{tanm})_{2}$ は，次世代 ジンク錯体として大いに注目されている.

\section{4. バナジルおよびジンク錯体の作用機構}

これまで紹介してきたバナジル及びジンク錯体は なぜ糖尿病治療に有効性を示すのかについて，さら に研究することとした，インスリンは，脂肪細胞の インスリン受容体に結合すると，その信号がインス リンシグナル伝達系と呼ばれる各種のタンパク質の リン酸化を促進することにより伝達され，プロテイ ンカイネース $\beta$ （PKB 又は $\mathrm{Akt} ）$ がリン酸化され ることにより，細胞内に存在していたグルコース輸 送体（GLUT4）を膜表面へ移動させる。その結果，

細胞外のグルコースが細胞内に取り込まれ，結果と して血糖值が低下するとともに，脂肪酸の細胞外へ の放出が抑制される現象が観測される。もし，イン スリンの代わりにバナジルやジンク錯体を加えた脂 肪細胞で同様の現象が観測できれば，それらの錯体 は明らかに上の機構により血糖降下作用を示すと説
明される，実際に，細胞内に存在する様々な酵素系 に作用する阻害剂や活性化剂を用いて検討したとこ ろ，これらの錯体は多くの酵素系にほぼ同時に作用 してインスリンと同様の作用を示すことを明らかに

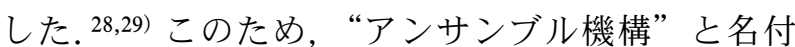
けた. (Fig. 3) 6,28,29)

さらに，インスリンと同様に，これらの錯体はグ ルコース輸送体（GLUT4）を細胞膜上へ移動させ ることを, GLUT4 の抗体と共焦点レーザー顕微鏡 を用いて，はじめて明らかにすることができた．錯 体の作用機構を分子レベルで基本的に理解できるよ うになってきたと考えている. ${ }^{30,31)}$

謝辞本研究の一部は, 文部科学省科学研究費 補助金 特別推進研究（平成 16-18 年度）の支援を 受けて行われた。関係各位に深く感謝申し上げる. 本総説は，筆者が徳島大学薬学部及び京都薬科大学 に在職中に行った研究成果を中心に述べたものであ る. 本研究に携わった上記両大学の多数の研究者, 大学院生及び学生諸君，さらに共同研究をして下さ った国内及び海外の研究者の多くの皆様に心から感 謝を申し上げる。 


\section{REFERENCES}

1) Ministry of Health, Labor and Welfare, Report of the investigation into the actual conditions of diabetes mellitus (2005).

2) WHO: Definition, diagnosis and classification of diabetes mellitus and its complication report of a WHO consultation. Part 1: Diaganosis and classification of diabetes mellitus, WHO Geneva (1999).

3) Sakurai H., Kagakukohgyo, 57, 249-254 (2006).

4) Sakurai H., "Encyclopedia of Bio-elements, Pharmaceuticals and Metal Elements,"' ed. by Sakurai H., Ohmsha, Tokyo, 2006, pp. 282287.

5) Sakurai H., Kojima Y., Yoshikawa Y., Kawabe K., Yasui H., Coord. Chem. Rev., 226, 187-198 (2002).

6) Sakurai H., Expert Opin. Drug Disc., 2, 873887 (2007).

7) Sakurai H., Kagaku, 62, 12-15 (2007).

8) Sakurai H., Farumashia, 39, 301-303 (2003).

9) Sakurai H., Vitamins (Japan), 80, 549-554 (2006).

10) Sakurai H., Tsuchiya K., Nakatsuka M., Kawada J., Ishikawa S., Yoshida H., Komatsu M., J. Clin. Biochem. Nutr., 8, 193200 (1990)

11) Fugono J., Fujimoto K., Yasui H., Kawabe K., Yoshikawa Y., Kojima Y., Sakurai H., Drug Metabol. Pharmacokin., 17, 340-347 (2002).

12) McNeill J. H., Yuen V. G., Hoveyda H. R., Orvig C., J. Med. Chem., 35, 1489-1491 (1992)

13) Sakurai H., Fujii K., Watanabe H., Tamura H., Biochem. Biophys. Res. Commun., 214, 1095-1101 (1995).

14) Watanabe H., Nakai M., Komazawa K., Sakurai H., J. Med. Chem., 37, 876-877 (1994).

15) Sakurai H., Inohara T., Adachi Y., Kawabe K., Yasui H., Takada J., Bioorg. Med. Chem., 14, 1093-1096 (2004).

16) Saha T. K., Adachi Y., Yoshikawa Y., Yasui
H., Sakurai H., Chem. Lett., 34, 1350-1351 (2005)

17) Sakurai H., Tayama K., Adachi Y., "Vanadium Compounds/Vanadate Oligomers in Biological Systems: Chemistry, Biochemistry and Biological Effects," ed. by Alves M. A., Research Signpost, India, 2007 (in press).

18) Adachi Y., Yoshida J., Kodera Y., Katoh A., Takeda J., Sakurai H., J. Med. Chem., 49, 3251-3256 (2006).

19) Adachi Y., Yoshikawa Y., Yoshida J., Kodera Y., Katoh A., Takada J., Sakurai H., Biochem. Biophys. Res. Commun., 345, 945950 (2006).

20) Cusi K., Cukier S., DeFronzo R. A., Torres M., Puchulu F. M., Redondo J. C., Clin. Endocrinol. Metab., 86, 1410-1417 (2001).

21) Sakurai H., Clin. Calcium, 15, 49-57 (2005).

22) Karmaker S., Saha T. K., Yoshikawa Y., Yasui H., Sakurai H., J. Inorg. Biochem., 100, 1535-1546 (2006).

23) Fugono J., Yasui H., Sakurai H., J. Pharm. Pharmacol., 57, 665-669 (2005).

24) Yoshikawa Y., Ueda E., Kawabe K., Miyake H., Takino T., Sakurai H., Kojima Y., J. Biol. Inorg. Chem., 7, 68-73 (2002).

25) Adachi Y., Yoshida J., Kodera Y., Katoh A., Yoshikawa Y., Kojima Y., Sakurai H., J. Biol. Inorg. Chem., 9, 885-893 (2004).

26) Adachi Y., Yoshida J., Kodera Y., Kiss T., Jakusch T., Enyedy E. A., Yoshikawa Y., Sakurai H., Biochem. Biophys. Res. Commun., 351, 165-170 (2006).

27) Adachi Y., Yoshida J., Kodera Y., Sakurai H., Chem. Lett., 34, 656-657 (2005).

28) Yoshikawa Y., Ueda E., Kojima Y., Sakurai H., Life Sci., 75, 741-751 (2004).

29) Kawabe K., Yoshikawa Y., Adachi Y., Sakurai H., Life Sci., 78, 2860-2866 (2006).

30) Basuki W., Hiromura M., Adachi Y., Tayama K., Hattori M., Sakurai H., Biochem. Biophys. Res. Commun., 349, 1163-1170 (2006) .

31) Basuki W., Hiromura M., Sakurai H., J. Inorg. Biochem., 101, 692-699 (2007). 